\title{
Legitimating the Union: Dilemmas of Citizens' and National Elites' Inclusion in a Multilevel Europe
}

\author{
Svetlozar Andreev
}

\begin{abstract}
It is often claimed that the EU suffers from a range of, occasionally, difficult-to-identify legitimacy problems. This is mainly because of its complex internal structure and way of functioning - i.e. between various levels of governance and centres of decision-making authority. This paper focuses on the role of citizens and national elites in granting support for the EU. The bottom-up approaches of legitimisation are thus explored. Special attention is paid to the participatory opportunities for citizens and national elites in multilevel governance.
\end{abstract}

THE ADVOCATES IF THE EUROPEAN UNION (EU) PROJECT HAVE CLEARLY BEEN ON THE defensive lately. The successive rejections of the Draft European Constitution (in Spring 2005) and the Lisbon Treaty (13 June 2008) came as major shocks for many, thus turning the relatively positive expectations of the early 2000s for 'more Europe and better functioning institutions' into feelings of gloom and paralysis. With remarkable ease, relatively ill-organised and loosely-fashioned coalitions of populists, nationalists and social protectionists in France, the Netherlands and Ireland managed to invalidate some of the most hard-negotiated international treaties guaranteeing the further progress of European integration. In all three cases, the response of member state elites and Brussels officials could be said to have been inadequate. What was proposed was to temporarily ignore the negative outcomes, and (1) to engage in diplomatic negotiations and analysis of the respective referendum results, (2) to improve the communication strategy regarding the benefits of adopting a particular European treaty, and (3) to persuade the leaders of the anti-EU camp to abandon their adamant opposition to supranational reforms by offering concessions at the domestic level. However, as time has passed, the prospect of reaching a compromise on the constitutional setup in Europe has become even slimmer, because public opinion and, occasionally, that of the political elites in certain member states, like the UK, the Netherlands, Poland and the Czech Republic - to name just a few of the most difficult cases - has shifted towards greater euroscepticism and opposition to the 'deepening' of European integration. As a result, the sanctioning of any major supranational decision - e.g. from enlargement to the adoption the Euro - via referendum has become increasingly difficult. This is because the electorate has firstly, become more politicised about European issues, and secondly been influenced by an increasing number of domestic politicians who have successfully utilised the 'blame the EU and 'Brussels' tactic for unpopular decisions made at home (see Beyers and Trondal 2003).

In spite of the growing feeling that time is running out for crucial reforms at the supranational level, the actual state of affairs has been fairly well-know to European scholars for at least two decades, if not longer. It has been dubbed a "crisis of legitimacy" or "legitimacy deficit" (Wallace 1993, Weiler 1993, Scharpf 1998, Héritier 
1999, Lord 1998 and 2000). The main symptoms of such a predicament, which has supposedly been plaguing the EU system of governance are the growing gap between the European elites and citizens, on the one hand, and the EU institutions and national political bodies, on the other. The reasons for the persistence of this complicated situation have been rampant too. Firstly, the "permissive consensus" 1 about supranational decision-making and institutional innovation, granted on mainly utilitarian grounds by the member states' populations, has steadily been waning since the mid-1980s (Neunreither 1994; Panebianco 1996; Scharpf 1999). Secondly, the increasing EU intervention in and Europeanisation of various policy areas (Olson 2001, Featherstone and Radaelli 2003, Bulmer 2007), some of which used to be the exclusive domain of the nation-state (e.g. foreign policy, social protection, migration policy, education and culture), has created a widespread sense of apprehension among domestic leaders and ordinary citizens that the process of regional integration might "redefine the political boundaries in Europe" (Weiler 1993: 18). Thirdly, the deepening of European integration has not been able to successfully protect the member state economies and societies from some of the negative effects of globalisation. On the contrary, instead of being "rescued" by the EU project (Milward 1992), the nations state has occasionally become further exposed to various external pressures, eventually leading to a profound transformation of the domestic socioeconomic and political systems (Mény et al. 1996; Scharpf 1997 and 1999; Hix 1999). Fourthly, the everincreasing legal activism of the European institutions and the establishment of different and sometimes new cross-national standards have led to strong resistance on the part of entrenched domestic interests and defenders of national constitutions (Joerges 2006). Parallel to this, there has been an introduction of concepts, relatively unfamiliar to member state public administrations, such as subsidiarity, proportionality, equal treatment, mainstreaming and benchmarking. This has spurred a debate about the capacity of domestic institutions and elites to effectively protect citizens' interests against the frequent encroachments by the EU "from above" and "outside" the member states (Wessels 1996; Streeck 2000; Eriksen 2001; Bartolini 2005). Fifthly, and certainly affecting public opinion most directly, the alleged inefficiency and lack of accountability of certain European officials, often resulting in allegations about widespread corruption at the heart of the $\mathrm{EU}$, has led people to prefer their domestic 'crooks' to the 'difficult to control and replace' supranational ones. The resignation of the Santer Commission in 1999 and the most recent media revelations about the illicit use by some MEPs of annual funds for travel and personal assistants have definitely enhanced such perceptions. As a result of these scandals, the reputation of EU institutions has been severely damaged, while the advancement of the European integration project has been rendered much more difficult by the increasingly staunch resistance on the part of domestic elites and groups of citizens.

This paper claims that the crisis of legitimacy in the EU has substantially deepened during the 2000s and is no longer been restricted to the supranational level of governance, but has increasingly spread to all levels of governance. Moreover, the proponents of European integration have been faced by a wider set of opposing elites, ranging from social movements to organised business interests and trade unions to national politicians. These groups are often extremely well organised and have significant international experience too. Therefore, EU leaders trying to solve the series of legitimacy problems mentioned above have had to simultaneously face (1) more complex and sometimes worse structural conditions and (2) many more and betterqualified opponents than in the past. If the first part of the 'legitimacy conundrum' has been the result of EU multilevel governance (MLG) activities and globalisation, factors that in and by themselves have been quite difficult to coordinate and control, then the second part of the equation - featuring real European actors - presents an opportunity

\footnotetext{
${ }^{1}$ Ronald Inglehart defines permissive consensus as a situation where "there is a favourably prevailing attitude towards the subject, but it was of low salience as a policy issue, leaving national decisionmakers to take steps favourable to integration if they wished but also leaving them a wide liberty of choice" (cited in Hodges 1972: 334).
} 
to address the legitimacy deficit. The research presented in this article focuses on the role of citizens and national political elites in granting support for European integration. Specifically, the bottom-up aspects of EU legitimisation are explored, while emphasis is placed on the modes of representation and participation of these two groups of actors.

The article is structured in the following way: first, the concept of legitimacy and different modes of legitimisation are described in detail; second, the role of citizens in EU governance is analysed in terms of different participatory opportunities and means of keeping decision-makers accountable; thirdly, the impact of the crisis of national democracy on European institutions and policies is critically evaluated; and finally, conclusions are drawn regarding the future of European integration in light of the present intricate legitimacy crisis.

\section{Legitimacy and Modes of Legitimisation in the EU}

Academics studying legitimacy problems in diverse social contexts, largely disagree about what legitimacy is and how to define this concept. They, nevertheless, concur that it has something to do with public support for political decisions, personalities and institutions (Blondel 1995: 62; Lord 2000: 1). Certain scholars posit that legitimacy can only be achieved if there is both attitudinal and behavioural support by 'the ruled' for 'the rulers' and their policies (Linz and Stepan 1996: 3). Conversely, no regime, even the most autocratic ones, can survive without the support, implicit or explicit, of its citizens. That is why, the majority of regimes around the world try to capitalise upon societal support by creating adequate institutional structures, as well as by promoting active relations with the representatives of civil society and the media. It should be emphasised however, that the rule of law plays an important part in this process; in particular constitutional rule, provides a means of establishing and formalising different channels of support (O'Donnell et al. 2004).

The backing, granted by both individuals and organisations, may vary substantially, depending on the circumstances. Hence, it should not be perceived as a clear-cut and fixed point, but more as a continuum. Authors, working on legitimacy issues, point out that support may also be general (for the overall political system) or specific (for individual policies) (Easton 1965: 311-1; Blondel 1995). At the same time, governmental decisions could be perceived as legitimate for what they achieve (substantive legitimacy) and for how they do it (procedural legitimacy) (Weber 1946) Thus, legitimacy implies the existence of a trade-off between efficiency and policy stability, on the one hand, and normative justice and political style, on the other (Lipset 1983; Diamond and Lipset 1994).

In terms of definition, Seymour Martin Lipset (1984: 88) presumes that "legitimacy involves the capacity of the system to engender and maintain the belief that the existing political institutions are the most appropriate ones for the society". Philippe Schmitter (2001: 2), on his part, conceptualises legitimacy as "a shared expectation among actors in an arrangement of asymmetric power, such that the actions of those who rule are accepted voluntarily by those who are ruled because the latter are convinced that the actions of the former conform to the pre-established norms. Put simply, legitimacy converts power into authority - Macht into Herrschaft - and, thereby, simultaneously establishes an obligation to obey and a right to rule".

Alongside the complicated question of defining what legitimacy actually is, political scientists have also reflected upon the possible ways of assuring legitimacy for a governing authority. Arguably, the process of legitimation is somewhat different from the concept of legitimacy, which is the object of this act. In his classical work "The Theory of Social and Economic Organisation", Max Weber identifies three ways of legitimation (or "three pure types of legitimate authority"): rational, traditional and 
charismatic (Weber 1964: 328). In more recent times, Fritz Scharpf (1997) has proclaimed that legitimacy can be secured either on the input or output side of government: input legitimacy, implying democratic selection of office holders, public consultation and electoral approval political programmes, while output legitimacy, referring to the necessity of directly attending to the public needs and, thus, ensuring that policy follows the public preferences and attitudes.

The legitimation of policies and decisions at the supranational ('European') level seems to present a certain amount of difference from the way legitimacy has been achieved at the state or sub-national level. For instance, students of European integration have concluded that political identity, loyalty and affiliation do not usually operate in the same way at various levels of governance (Wallace 1993: 100). According to Ernst Haas' neo-functionalist vision of Europe, the pursuit of different shared sectional benefits promotes a "patchwork quilt of support" across many and diverse societal interests and policy areas (Haas 1958: 16). Based on the classical writings of Leo Lindberg, Stein Scheingold and Karl Deutsch, Stefania Panebianco (1996) distinguishes theoretically between utilitarian and affective support ${ }^{2}$ for the EU among the member states' citizens. At the same time, she provides empirical evidence regarding the fact that the first usually predominates (Panebianco 1996: 5). A parallel track of research has been concerned with the importance of law, both national and international. For instance, the American scholar Joseph Weiler refers to "formal" or constitutional legitimisation of the EU, since, in his mind, the creation of all European institutions has been sanctioned by law (Weiler 1993: 19 and 1999b). Both Daniela Obradovic and Fritz Scharpf agree that the single use of the law and the implementation of constitutional reforms are not sufficient to provide enough legitimacy for the European political and governance system, but their role should nevertheless be taken into serious consideration (Obradovic 1996: 197;, Scharpf 1994: 220). Finally, Markus Höreth (1998:30) concludes that the legitimisation of European governance presents a multidimensional and complex problem in and by itself, that's why international law helps structure this process.

Scholars, working on the legitimacy problems in the EU, have identified at least four main types of legitimisation (Scharpf 1994 and 1999b; Höreth 1998 and 2001; Weiler 1999):

1) Output legitimacy: support, granted on the basis of improved efficiency in provision of goods and services, as well as an increased European problemsolving capacity - government for the people;

2) Input legitimacy: Direct legitimation through the elected European Parliament; citizens' participation and consultation; better transparency in taking decisions government by the people;

3) "Borrowed" legitimacy: Indirect legitimation through the Member States and their democratic representatives operating at different levels - government of the people;

4) Constitutional legitimacy: Formal legitimation through European and international law - government by the 'rule of law'.

The research on democratic legitimacy in the EU has overall concluded that supranational authorities have traditionally relied on the first and third types of legitimisation (Scharpf 1994 and 1999; Wessels and Diedrichs 1997; Höreth 1998;

\footnotetext{
${ }^{2}$ Utilitarian support "for the supranational institutions is support for integration which stems from a recognition of common interests and positive, mutual benefits that will result" (Lindberg and Scheingold 1970, cited in Panebianco 1996: 5). Affective support is "emotional support which may exist between peoples, and which may also comprise a sense of common identity" (Deutsch, cited in Panebianco 1996: 5).
} 
Moravcsik 2002). On the one hand, the technocratic and utilitarian side of the functioning of the Brussels bureaucracy, i.e. by being able to redistribute various resources and allocate political and social values across various levels of governance (Majone 1996 and 2001), has always been seen as an important reason for the existence of the EU. On the other hand, the democratic "rule of law" within the member states and the expanding scope of Community law, achieved through a series of formal revisions of the European treaties and the legal activism of the European Court of Justice (ECJ), have been considered instrumental for the supranational institutions to "borrow" legitimacy from the member states' democratic experience (Obradovic 1996; Joerges 2006). The recent practice of both types of legitimisation has incited a debate about the 'sufficiency' of using output and borrowed legitimacy for assuring support for EU institutions and policies. There have not only been some scholars (Majone 1998; Moravcsik 2002 and 2004; Crombez 2003), but also EU officials, who have declared that the EU is sufficiently legitimated by referring to the member states as a source of popular support. For instance, in the White Paper on Governance (2001), attention is drawn to the fact that "[t]he Union is built on the rule of law; it can draw on the Chapter of Fundamental Rights, and it has a double democratic mandate through a Parliament representing EU citizens and a Council representing the elected governments of the Member States" (European Commission 2001a: 7). Moreover, the aforementioned social scientists have pointed out to the limited capacity of the European institutions to effectively influence member states representatives during decision-making and to control national administrations during implementation. A different group of scholars has mostly focused on the limited role of the European and national parliaments within the EU system of governance (Neunreither 1994; Hix 2008). It has been pointed out that the European citizens directly elect the European Parliament (EP) indeed, but the latter has been the only such EU institution. At the same time, elections for the EP have not been extremely popular among national politicians and member state populations, while its legislative and decision-making powers remain relatively weak, albeit growing (Blondel et al. 1998; Rittberger 2005). The political role of national parliaments in multilevel Europe has not been clarified either (Magnette 2000; Follesdal and Hix 2005), especially after the Irish debacle with the ratification of the Lisbon treaty.

Parallel to this, things have recently changed much more radically and faster with respect to various formal and informal requirements for governing the Union as a network of policy actors (Eising 2007; Zielonka 2007). The increasing Europeanisation of different policy areas since Maastricht and the separation of national and supranational spheres of activity has left both domestic leaders and civil society groups demanding more transparency and accountability from the European elites. Under such circumstances, it has become increasingly obvious that the growing body of unsatisfied and underrepresented European citizens should somehow be given more say in European matters (i.e. 'input legitimacy'). As Frank Schimmelfennig (1996: 2) has concluded, "[t]he more power over issues of core state sovereignty and redistribution was transferred to the European level, the more the Community was in need of its own sources of direct popular support". Accordingly, different forms of input legitimacy for the citizens and interest groups have been conceived (Warleigh 1998; Bellamy and Warleigh 2001). For instance, European citizenship was formally created in the early 1990s, while the debate initiated by the White Paper on Governance in Europe has mainly been concerned with the role of "civil society" (Eriksen 2001; Höreth 2001). Regarding the fourth type of legitimisation, 'Constitutional Legitimacy', the treaty drafting and revision process has been quite dynamic since the early 2000s (vide the work of the Convention on the Future of Europe and the recent Lisbon Treaty reform). However, it repeatedly stalled when popular referenda were called or when the leaders of selected member states failed to grant their unconditional support. Hence, the practical realisation of this type of legitimisation has not only been dependent upon the opinion of supranational elites, but also upon the backing of different national and sub-national actors, most notably various civic leaders and local politicians. 


\section{Active Civic Participation - Expectations and Pitfalls}

Although citizens have traditionally not been at the centre of European political decision making (Neunreither 1995), both ruling elites and academics have recognised their occasionally important role throughout the history of European integration. This perception was further reinforced during the 1990s with the adoption of the TEU and the instauration of a formal European citizenship (Pinheiro 1993; European Commission $2001 \mathrm{~b}$; Bellamy and Warleigh 2001). Two important steps towards the practical implementation of such citizenship were the stipulation of the rights of the European citizens in the Maastricht Treaty (TEU 1992, arts. 8a-e) and the creation of various transparency and accountability mechanism by the EU administration (Shaw 1997; Héritier 1999). The necessity to increasingly consult citizens, in order to improve and legitimate most of the decisions taken at the supranational level, gradually evolved towards a more direct involvement of civic and professional organisations in the preparation and implementation of these decisions (Armstrong 2002). For example, the Economic and Social Committee and the Committee of the Regions, were promoted as official consultative bodies with distinct purposes, and there was a move towards the informal engagement of various lobby groups in the work of different expert committees in Brussels (Andersen and Eliassen 1998). During the early 2000s, the Convention on the Future of Europe, composed of representatives from all current and future member states, as well as from the EU institutions, had set up as an ambitious goal for itself to draw a proposal for a "constitution for the European citizens" (Laeken Declaration 2001). The successive inclusion of civic and special interest groups in the Convention on the Charter of Fundamental Rights (December 1999 - October 2000) and the Convention on the Future of Europe (February 2002 - June 2003) was considered a symbolic act of great public relation importance, which legitimated both legal documents to a larger extent.

What motivated the supranational elites to pay better attention to citizens' interests? The answer could be found in some key political and social events during the 1990s, which managed to impact EU stability and threatened to derail possible enlargement and the deepening of the EU institutions and policy process. To start with, Danish voters initially rejected the Maastricht Treaty (2 June 1992), while the referenda in France and Ireland barely managed to pass the necessary majority mark. The completion of the internal market and especially the adoption of the Euro were also met with great suspicion by certain member states (Weiler 1993; Magnette 2000). Towards the late 1990s, some EU institutions (i.e. Eurostat and the European Commission) got involved in high-profile corruption scandals that shook the supranational administration. During the same period, the European Ombudsman and EP started to receive a large number of petitions from concerned European citizens and interest groups. Accordingly, both institutions, together with the European Court of Auditors, began to take their controlling functions very seriously. They sent more requests for clarification to the relevant EU bodies than ever before in the past. Parallel to this, OLAF (the EU anticorruption agency) was profoundly reorganised and boosted its activities to cover all Community-related activities. Finally, the ECJ began to interpret the provisions of European citizenship (Shaw 1998), while continuing to exert control on both member states and supranational institutions regarding potential infringements of the treaties (Sandholtz and Stone Sweet 1998).

As a result of these important political and structural developments, EU representatives launched a public discussion about the possibility of an emerging legitimacy crisis in Europe (European Parliament 1996; European Commission 2001a and 2001b). Although there was no formal consensus about the exact dimensions and consequences of such a predicament, an agreement was reached that something had to be done to prevent it, particularly in light of the processes concerning the introduction of the Euro and future accession of new member states (Lebessis and Paterson 1999; Laeken Declaration 2001). One of the principal proposals was to include representatives of civil society in EU decision-making, thus attempting to close the 
confidence gap between the European elites and citizens. A key measure, underpinning this process, was the promotion of "active civic participation" in various EU initiatives (Lebessis and Paterson 1997 and 1999). The dialogue with supranational civil society was duly intensified, while various networks of European interest groups and social movements (the so-called stakeholders) were simultaneously coordinated and sponsored by Brussels (Héritier 1999; Eising 2007). Moreover, during the second half of the 1990s, individual EU bodies and the Commission in particular proposed that civic groups should also contribute to the preparatory and implementation phases of different European projects by investing their own resources and specific expertise (Smismans 1999; De Schutter 2002). Since then, the trend has clearly been from consultation towards direct participation of such groups. Ultimately, the involvement of 'active citizens' in EU decision-making was perceived, albeit sometimes quite vaguely, as an important factor enhancing the "general level of civic consciousness and participation" (Magnette 2003). It was presumed that this latter process could lead to the creation of more coherent supranational communication and public spaces, thus eventually contributing to the formation of a common European identity and even of a European demos (Habermas 1992 and 1998; Weiler 1999, Jolly 2007).

Despite the increased activism by EU representatives, three chief problems were identified in relation to the possible participation of European citizens and interest groups. Firstly, the lack of resources and opportunity structures for participation of various societal organisations at the supranational level was singled out as particularly critical (Nentwitch 1996 and 1998; Eising 2007). Secondly, the customary definition of European "civil society" was misleadingly used to denote large transnational businesses and lobbyists, while a relatively small number of truly European civic organisations or groups of individuals were admitted as stakeholders in EU decision-making (Andersen and Eliassen 1998; Kohler-Koh 1997 and 2000). Thirdly, the thinness of the concept of supranational citizenship and lack of European identity led to a clear deficit in political participation of both individuals and parties at the supranational level (Mair 1995; Magnette 2003).

In order to fully understand the difficulties facing 'active civic participation' in Europe, it is worth trying to expand a little bit more upon this set of issues. Regarding the limited participatory opportunities for ordinary citizens and grass-root organisations in a multilevel Europe, the problem has been a dual one - of both rights and resources. For instance, civic groups and individuals have rarely had access to supranational deliberations (i.e. in the work of the Conventions or during everyday decision-making at Community level) because they had to register with the respective European institutions in advance. At the same time, they have been discriminated against, at least compared to influential trade union or employers confederations that have traditionally been the 'privileged partners' of decision-makers in Brussels or Strasbourg. The same goes for the contrast with large domestic business and regional associations, which have preferred to directly lobby member state representatives, thus precluding ordinary people and small societal groups from having a consequential impact over the final ruling of EU leaders. A related problem has been that of resources. Not only have grass-root organisations been sidelined during EU decision-making, but they have also not been able to benefit from the same amount of financial and conceptual resources as their much larger counterparts (Kohler-Koch 2000). Hence, the notion of "civil society", as used by the European bureaucracy and political elites, has been one of the most contested (Smismans 1999; De Schutter 2002).

Apart from being predominantly coordinated and sponsored from above (i.e. the EU Commission), the already-described civic participation has been seen as quite elitist too (Magnette 2003). The primary reason for this has not so much been the privileged access granted to big international organisations and lobbyists in Brussels, but the unaccountable way the representatives of these organisations have been relating to their members and the general European public before, during and after participation at the supranational level. The presumable lack of connection between civil society 
elites and their followers has been singled out as an additional key factor for the missed opportunity for developing a true European public sphere and political parties (Dehousse 1995; Héritier 1999).

Ultimately, the problems of active civic participation have also been linked to the evolution of the concept of European citizenship and the acquiring of supranational identity. Above all, it should be pointed out that more than a decade and half since its creation the practical meaning of being a citizen of Europe has not really been understood, by citizen or politician alike. Numerous studies, especially after the 1997 Amsterdam Intergovernmental Conference (IGC), which modified the TEU, demonstrated that the progress in developing a true European citizenship has been "frozen" by EU politicians (Bellamy and Warleigh 2001; Warleigh 1998; Wiener 1998). No apparent progress has been made during the 2000s either, despite the legal activism of ECJ on some key European citizenship cases. Furthermore, the development of common European identity has not advanced very much either (Jolly 2007). Some scholars, who had previously argued that this process would stabilise and legitimate the EU system of governance from below, have had to eventually admit that the emergence of a European demos is highly unlikely in the foreseeable future (Weiler 1999, Chryssouchoou 2001, Ehin 2008). At the same time, it was estimated that various means of legitimisation - alongside input legitimacy via its identity component - had to simultaneously be combined in order to effectively support the credentials of the EU as a "composite democracy" (Héritier 2003).

\section{The Crisis of National Democracy and its Impact upon the Attitude of Domestic Elites towards Europe}

Ever since the completion of the Internal Market during the early 1990s and the adoption of the Maastricht treaty, the EU has been described as a "polity in formation" (Sbragia 1992). Due to the ongoing institutional reforms and policy scope expansion (including both internal and foreign policy aspects), the political setup within the Union has become ever more complex. The ambitious programme of adopting both the Euro and enlarging the EU to the East and South has also added to the practical complication of this process. In such conditions, the role of policy experts and lawyers has allegedly become more important, while that of politicians - especially national and sub-national ones - has been on a decline (Majone 2001). That is why, some scholars have been quick to proclaim that the new governance in Europe has been predominantly technocratic and, hence, less accountable (Obradovic 1996; Eriksen 2001). The research on multilevel governance has generally been supportive of this thesis (Scharpf 1994; Hooghe and Marks 2005), because it has been proven that, since the creation of the EU, power has increasingly been dispersed between various centres of authority and the opaqueness within parts of the system has increased (Dehousse 1998; Schmitter 2000). An added problem, identified by scholars of European integration has been that not all relevant policy concerns of the electorate and domestic politicians have effectively been met by the development of supranational governance (Crombez 2003; Moravcsik 2004; Ehin 2008), thus the 'still functioning till now' output and 'borrowed types of legitimacy' have apparently stalled. Moreover, the permissive consensus and delegation of authority by the wider European public could no longer be applied indiscriminately (Pollack 2000). Rather, as the experience with the blocked ratification of the Draft European Constitution and Lisbon Treaty demonstrated, even though consensus might have existed among European elites at the supranational level, the opinion of previously ignored and isolated internationally domestic leaders and constituencies should also have been taken into considerations preferably in advance (Lord 2004).

The above dynamic developments have led to the rapid growth of some unfortunate practices involving domestic elites, particularly at the national and sub-national level of governance. Notably, the "switching of burden" and "blame-shifting" by member state 
politicians to the EU, the latter being used as a scapegoat for some possible failures at home or at international arena (Eriksen and Fossum 2000; Beyers and Trondal 2003), have been on the rise lately. It is interesting to note, that in virtually all these cases, domestic leaders have proposed no solution about how to address the emerging problems in Europe or how to punish, for that matter, the supranational authorities for their supposed wrongdoings. Despite the fact that a good part of all this could be epitomised as sheer populism and empty rhetoric, it has been highly profitable for political elites at home. Recently, the trend has been that not only do opposition groups within the member states and eurosceptics argue against the EU, but increasingly people in power, who participate in decision-making at the supranational level, are also beginning to adopt a 'blame Brussels' rhetoric, thus using the momentum of public discontent for their own purposes as well.

Such a lack of resilience by national elites to the 'temptations' of populism, which simultaneously undermines European integration, has led some social scientists to pay closer attention to the possible crisis of national democracy and link this problem to the weakened legitimacy of the EU. First and foremost, it should be pointed out that the EU is a complex governance structure, composed of twenty-seven different states. For good or ill, all current member states are relatively well-functioning democratic regimes, with their own political systems and traditions. Nonetheless, sometimes people tend to unintentionally draw conclusions about the features of European democracy by using the same standards, which are applicable at the national level (Banchoff and Smith 1999). Such 'isomorphism' between the quality of the political regime in the member states and in the $E U$ is vastly misleading for those looking for a legitimacy deficit at the European level. Secondly, it is not irrelevant to know what changes occur with democracy at the national and sub-national level, because numerous veto players might emerge from below and determine the final outcome during supranational deliberations (Tsebelis 2002; Scharpf 2006). This issue has become quite pertinent with the inclusion of many fledgling democracies from Central and Eastern Europe during the latest wave of enlargement. Problems of migration, terrorism and regional separatism have also catalysed different transformation processes within the old member states, occasionally leading to radical changes of the parties in power and the political system as a whole. Thirdly, and probably less directly related to the crisis of national democracy, but by analysing the EU-member state relationship from a different angle, it is possible to observe how the image of various international organisations has been suffering, leading to their detachment from the problems of the people in a post-Cold War world. During the last two decades, major international organisations have often been criticised of extreme neo-liberalism and lack of accountability. The violent protests, organised against the meetings of the World Trade Organisation (WTO), G8 and International Monetary Fund (IMF) during the early 2000s, led people to believe that there has been a growing discontent with, at least, some of the policies of these international organisations. The EU, which is certainly been a combination of a supranational polity and international organisation, has occasionally been unintentionally associated with the problems of globalisation and blamed by the European public for them. At the same time, the demonstrations of powerful sectoral groups, such as agriculturalists, fishermen, lorry drivers and environmentalists, in front of the European institutions have captured media attention, thus further deligimating the EU as a presumably insensitive and remote from the real problems international organisation. It comes as no surprise that various protectionists and eurosceptics have often used this incorrect perception, in order to claim more power for the member states and less supranational authority.

However, domestic democracy has been experiencing its own serious problems as well. "Symptoms of morbidity" of the political system (Schmitter 2003), such as an overall disapproval of the performance of the political institutions, low voter turnout in elections and falling party membership have been on the rise around the world. Contestation and litigation against the legal procedures at the national and subnational level have been widespread too. Furthermore, the increased awareness 
among national leaders about the effects of European integration on member state political systems has rendered these elites oversensitive towards any reform at the supranational level. Because of the unexpected and occasionally undesirable events taking place as a result of EU interventionism, domestic elites increasingly started to pay attention to the weakness of national democracy too (Mény et al. 1996). Overall, there has been increasing evidence that domestic politics in both established and new democracies have been suffering from some form of "a general crisis of legitimacy," accompanied by the rise of extremist and populist tendencies in society (Mény and Surel 2000).

In sum, it could be presumed that, during the last decade or so, the functioning of the EU has been influenced by and, in a certain way, embedded in the domestic and, partly, in the international environment. Because a great number of political problems, attributed to the EU, have been present both at the national and global level, the image of this latter organisation as an efficient and democratic polity has been suffering as well. In other words, the EU has often been forced to operate at and mediate between different levels of governance - national, sub-national and global - and, as a consequence, be unjustly blamed by the citizens and various elite groups for being unaccountable and illegitimate.

\section{Conclusion}

Seymour Martin Lipset (1984: 89) once famously stated with respect to the rapidly evolving nature of the modern state that "the crisis of legitimacy is a crisis of change". This statement seems quite appropriate nowadays with respect to the ongoing transformation of the governance system of the EU. Despite the successful completion of the Internal Market, the adoption of the Euro and the enlargement of the Union towards twelve new member states, the more the EU has changed, the more opposition it has provoked both at the national and at the supranational level.

Some people claim that the EU has been suffering from a range of occasionally difficultto-identify legitimacy problems. This has mainly been because of its complex institutional structure and way of functioning. Moreover, the possible ways of addressing the alleged democratic deficit or of solving some of the legitimacy problems in the EU have predominantly centred on the top-down and traditional institutionalist approaches, which try to remedy the structural imbalances at the supranational level. The discussions of both academics and practitioners have not always paid proper attention to citizens and national elites, hence there has been an acute need to cover the bottom-up dimension of legitimisation in much greater detail, in order to account for the variety of legitimacy problems arising in a particular context.

This article has addressed some of the bottom-up aspects of legitimacy, namely the role of citizens and national elites. By analysing the different modes of legitimation within the complex multilevel structure of the EU, it has been proven that the traditional output and borrowed legitimacy types could not be applied single-handedly, but need to be supplemented with input and constitutional ways of legitimation. Since the latter mode is often contingent upon popular and national elites support, the actual research has mainly focused on different input types of legitimacy.

In spite of the major advances made by the EU institutions to include civic and interest groups in supranational decision-making, there have been persistent problems that have prevented European elites from closing the legitimacy gap with the member state populations. The limited participatory opportunities, lack of resources, biased selection of civil society and interest groups partners, and a poorly developed concept of European citizenship have been some of the problems singled out in this article. Moreover, the slow progress in consolidating a meaningful European identity could be cited as an additional impeding factor towards greater bottom-up participation. 
This article has also paid attention to the crisis of national democracies as influencing the legitimacy deficit at all levels of governance within the EU. The 'morbidity' of the political system at home has incited national politicians and elites to seek compensation at the supranational level. Taking into account its own legitimacy problems and limited possibility to act in certain areas, the EU has not been able to respond adequately to demands from below. As a result, it has become an easy target for national populists and eurosceptics. Finally, the crisis in the global system of governance, involving some of the most influential international organisations, has unintentionally affected the EU as well. The latter position has been a difficult one embedded between many and disparate levels of governance. The EU has been trying to accommodate the interests of various players at the same time, while simultaneously protecting itself from the suspicions of being too technocratic and unaccountable.

\section{References}

Andersen, Svein S. and Eliassen, Kjell A. (eds.) (1998). 'EU Lobbying - Towards Political Segmentation in the European Union?', in P-H. Clays, C. Gobin, I. Smets and P. Winand (eds.) Lobbying, Pluralism and European Integration Brussels: European Interuniversity Press, pp. 167-82.

Armstrong, K.A. (2002). 'Rediscovering Civil Society: The European Union and the White Paper on Governance', European Law Journal, 8 (1), pp. 102-132.

Banchoff, Thomas and Smith, Mitchel P. (1999). Legitimacy and the European Union, London: Routledge.

Bartolini, S. (2005). Restructuring Europe. Centre Formation, System Building, and Political Structuring between the Nation State and the European Union. Oxford University Press,

Bellamy, R. and Warleigh, A. (1998). 'From Ethics of Integration to an Ethics of Participation: Citizenship and the Future of the European Union', Millennium, 27, pp. 447-70.

Bellamy, R. and Warleigh, A. (eds.) (2001). Citizenship and Governance in the European Union. London: Continuum.

Beyers, J. and Trondal, J. (2003). 'How Nation-States 'Hit' Europe - Ambiguity and Representation in the European Union', EioP Working Paper, 7 (5). Available at: http://eiop.or.at/eiop/pdf/2003-005.pdf.

Blondel, J. (1995). Comparative Government. An Introduction. London: Prentice Hall.

Blondel, J., Sinnott, R. and Svensson, P. (1998). People Parliament and the European Union. Participation, Democracy and Legitimacy. Oxford: Clarendon Press.

Bulmer, S. (2007). 'Theorizing Europeanization', in Paolo Graziano and Martin P. Vink (eds.) Europeanization: New Research Agendas. London: Palgrave/Macmillan, pp. 46-58.

Chryssouchoou, D. N. (2001). Theorizing European Integration. London: Sage.

Crombez, C. (2003). 'The Democratic Deficit of the European Union. Much Ado about Nothing?, in European Union Politics, 4 (1), pp. 101-120.

De Schutter, O. (2002). 'Europe in Search of Its Civil Society, European Law Journal, 8 (2), pp. 198-217.

Dehousse, R. (1995). 'Institutional reform in the European Community: Are there Alternatives to the Majoritarian Avenue?', EUI Working Paper, RSC 95/4, Florence 1995.

Dehousse, R. (1998). 'European Institutional Architecture after Amsterdam: Parliamentary System of Regulatory Structure?', EUI Working Paper, RSC 98/11, Florence.

Diamond, L. and Lipset, S.M. (1994). 'Legitimacy', entry in the Encyclopaedia of Democracy, pp. 747-51.

Easton, D. (1965). A System Analysis of Political Life. New York: Wiley, pp. 311-319. 
Ehin, P. (2008). 'Competing Models of EU Legitimacy: the Test of Popular Expectations', JCMS, 46 (3), pp. 619-640.

Eising, R. (2007). 'Interest Groups and Social Movements', in P. Graziano and M. P. Vink (eds.), Europeanization: New Research Agendas. London: Palgrave/Macmillan, pp. 167-181.

Eriksen, E. (2001) 'Democratic or Technocratic Governance?', Jean Monnet Working Paper No. 6/01, Harvard Law School European Union Program.

Eriksen, E. and Fossum, J. (eds.) (2000). Democracy in the European Union - Integration through Deliberation? London: Routledge.

European Commission (2001a). European Governance: a White Paper, COM (2001) 428 final.

European Commission (2001b). Report of Working Group on Consultation and Participation of Civil Society. Rapporteur: M. Kroeger.

European Parliament (1996). Summary Report on the Public Hearing "The Intergovernmental Conference 1996: The European Parliament - A Heaven for the Concerns of the Citizens", A4-0068/96 of 3 and 27 March 1996.

Featherstone, K. and Radaelli, C. (eds.) (2003). The Politics of Europeanization. Oxford: Oxford University Press.

Follesdal, A. and Hix, S. (2005). 'Why There is a Democratic Deficit in the EU: a Response to Majone and Moravcsik', European Governance Paper, No. C-05-02, CONNEX/NEWGOV research network.

Haas, E, B. (1958). The Uniting Europe. Political, Social and Economical Forces. 1950-1957. Stanford: Stanford University Press, 1958.

Habermas, J. (1992). 'Citizenship and National Identity: Some Reflections on the Future of Europe', Praxis International, 12, pp. 1-19.

Habermas, J. (1998). 'The European Nation-State: On the Past and Future of Sovereignty and Citizenship', in: Political Culture, 10 (2), pp.197-416.

Héritier, A. (1999). 'Elements of Democratic Legitimation in Europe: An Alternative Perspective', Journal of European Public Policy, 6 (2), pp. 269-82.

Héritier, A. (2003). 'Composite Democracy in Europe: the Role of Transparency and Access of Information', Journal of European Public Policy, 10 (5), pp. 814-833.

Hix, S.(1999). The Political System of the European Union. London: Macmillan.

Hix, S. (2008). What's Wrong with the European Union and How to Fix it. Cambridge: Polity Press.

Hodges, M. (ed.) (1972). European Integration. Harmondworth: Penguin.

Hooghe, L. and Marks, G. (2005). 'The Neofunctionalists were (almost) Right: Politicization and European Integration', Constitutionalism Web-Papers, ConWEB No. 5/ 2005.

Höreth, M. (1998) 'The Trilemma of Legitimacy - Multilevel Governance in the EU and the Problem of Democracy', ZEI Discussion Papers, Vol. C, No. 11, Bonn, Germany;

Höreth, M. (2001).'The European Commission's White Paper on Governance: A 'Tool-Kit' for Closing the Legitimacy Gap of EU Policy-Making', ZEI Discussion Papers, Vol. C, No. 94, Bonn, Germany.

Joerges, C.(2006).'"Deliberative Political Processes" Revisited: What Have We Learnt about the Legitimacy of Supranational Decision-Making', Journal of Common Market Studies, 44 (4), pp. 779-802.

Jolly, M. (2007). The European Union and the People. Oxford: Oxford University Press.

Kohler-Koch, B. (2000). "'Framing": the Bottleneck of Constructing Legitimate Institutions', Journal of European Public Policy, 7 (4), pp. 513-31.

Laeken Declaration (2001) 'Laeken Declaration on the Future of the European Union', 15 December 2001, SN 300/01 ADD1.

Lebessis, N. and Paterson, J. (1997). 'Evolution of Governance: What Lessons for the Commission? A First Assessment', Brussels: European Commission, Forward Studies Unit Working Paper.

Lebessis, N. and Paterson, J. (1999). 'Improving the Effectiveness and Legitimacy of EU Governance: a Possible Reform Agenda for the Commission', Brussels: European Commission, Forward Studies Unit Working Paper; 
Lindberg, L.N. and Scheingold, S.A. (1970). Europe's Would-be Polity. Patterns of Change in the European Community. Englewood Cliffs, New Jersey: Prentice Hall.

Linz, J. and Stepan, A. (eds.) (1996). Problems of Democratic Transition and Consolidation: Southern Europe, Latin America and Post-Communist Europe. Baltimore, MD: Johns Hopkins University Press.

Lipset, S. M. (ed.) (1983). Political Man: The Social Bases of Politics. Aldershot: Gover, 1983.

Lipset, S.M. (1984) 'Social Conflict, Legitimacy, and Democracy', reprinted in William Connolly (ed.) Legitimacy and the State. Oxford: Basil Blackwell, pp. 88-103; originally published in S.M. Lipset (ed.) Political Man: The Social Bases of Politics. Baltimore, MD: Johns Hopkins University Press, 1981.

Lord, C. (1998) Democracy in the EU. (Sheffield: UACES, Sheffield Academic Press.

Lord, C. (2000). 'Legitimacy, Democracy and the EU: When Abstract Questions Become Practice Policy Problems', Policy Paper 03/00, ESRC Programme "One Europe or Several?.

Lord, C. (2004). A Democratic Audit of the European Union. Houndmills: Palgrave Macmillan.

Magnette, P. (2000) 'Towards 'Accountable Independence'? Parliamentary Controls of the European Central Bank and the Rise of a New Democratic Model', European Law Journal, 6 (4), pp. 326-40.

Magnette, P. (2003). 'European Governance and Civic Participation: Beyond Elitist Citizenship?', Political Studies 51, pp. 144-160.

Mair, P. (1995). 'Political Parties, Popular Legitimacy and Public Privilege', Western European Politics (18) 3, pp. 40-57.

Majone, G. (1996. 'Regulatory Legitimacy', in G. Majone (ed.) Regulating Europe. London: Routledge, pp. 284-301.

Majone, G. (1998). 'Europe's "Democratic Deficit": The Question of Standards', European Law Journal, 4 (1), pp. 5-28.

Majone, G. (2001). 'Nonmajoritarian Institutions and the Limits of Democratic Governance: A Political Transaction-Cost Approach', Journal of Institutional and Theoretical Economics 157 (1), pp. 57-78.

Mény Y., Muller, P. and Quermonne, Jean-Louis (eds.) (1996) 'Introduction', in Adjusting to Europe: The impact of the European Union on National Institutions and Policies. London: Routledge. pp. 1-22.

Mény, Ives and Surel, Ives (2000). Par le people, et pour le peuple: le populisme et les démocraties. Paris: Fayard.

Milward, A. (1992). The European Rescue of the Nation State. London: Routledge.

Moravcsik, A. (2002). 'In Defence of the "Democratic Deficit": Reassessing Legitimacy in the European Union, Journal of Common Market Studies, 40 (4), pp. 603-24.

Moravcsik, A. (2004). "Is there a "Democratic Deficit" in World Politics? A Framework for Analysis', Government and Opposition, 39 (2), pp. 336-63.

Nentwich, M. (1996). 'Opportunity Structures for Citizens' Participation: The Case of the European Union', European Integration Papers Online (1996), No. 1, available at: http://eiop.or.at/eiop/texte/1996-001a.htm.

Nentwich, M. (1998). 'Opportunity Structures for Citizens' Participation: The Case of the European Union', in M. Nentwich and A. Weale. (eds.), Political Theory and the European Union: Legitimacy, Constitutional Choice and Citizenship. London: Routledge.

Neunreither, K. (1994). 'The Democratic Deficit of the European Union: Towards Closer Cooperation between the European Parliament and the National Parliaments', Government and Opposition, 29 (3), pp. 299-314.

Neunreither, K. (1995) 'Citizens and the Exercise of Power in the European Union: Towards a New Social Contract?', in A. Rosas and E. Antola (eds.), A Citizens' Europe: In Search of a New Order. London: Sage

Obradovic, D. (1996).'Policy Legitimacy and the European Union', Journal of Common Market Studies 34 (1996), pp. 191-221.

O'Donnell, G, Vargas Cullell, J., and lazzetta, O. M. (2004). The Quality of Democracy: Theory and Applications. Notre Dame: University of Notre Dame Press. 
Olson, J. P. (2001) 'The Many Faces of Europeanisation', ARENA Working Papers WP 01/2, 2001, pp. 1-47; available at: http://www.arena.uio.no/publications/wp02_2.htm.

Panebianco, S. (1996). 'European Citizenship and European Identity: from the Treaty of Maastricht to Public Opinion Attitudes', Jean Monnet Working Papers in Comparative and International Politics, University of Catania, Italy, (December 1996), Jean Monnet Working Paper, 03/96, available at: http://aei.pitt.edu/384/01/jmwp03.htm.

Pinheiro, J. (1993). Communication to the Commission, 28 July 1993. SEC (93) 1246/3.

Polack, M.A. (2000). Contribution to ECSA Review Forum on "Democracy and Constitutionalism in the European Union", ECSA Review (13:2), Spring 2000, pp. 2-7.

Rittberger, B. (2005). Building Europe's Parliament. Democratic Representation Beyond the Nation-State. Oxford: Oxford University Press.

Sandholtz, W. and Stone Sweet, A. (eds.) (1998). European Integration and Supranational Governance. Oxford: Oxford University Press.

Sbragia, A. M. (1992). "Thinking about the European Future: The Uses of Comparison", in A. Sbragia (ed.) Euro-Politics: Institutions and Policymaking in the 'New' European Community. Washington, DC: The Brookings Institution, pp. 257-291.

Scharpf, F. (1994). 'Community and Autonomy: Multilevel Policy-Making in the European Union', Journal of European Public Policy 1, pp. 219-42.

Scharpf, F. (1997). 'Economic Integration, Democracy and the Welfare State', Journal of European Public Policy, 4 (1), pp. 18-36.

Scharpf, F. (1998). 'Interdependence and Democratic Legitimation', MPIfG Working Paper 98/2, Bonn, Germany.

Scharpf, F. (1999). Governing in Europe. Democratic and Efficient? Oxford: Oxford University Press.

Scharpf, F. (2006). 'The Joint-Decision Trap Revisited, Journal of Common Market Studies, 44 (4), pp. 845-64.

Schimmelfennig, F. (1996). 'Legitimate Rule in the European Union. The Academic Debate', Tübingen University Working Papers in International Politics and Peace Studies, No. 27, Tübingen, Germany.

Schmitter, P.C. (2000). How to Democratize the European Union...and Why Bother? Lanham: Rowman \& Littlefield.

Schmitter, P.C. (2001) 'What is There to Legitimize in the European Union...and how Might This be Accomplished?', Jean Monnet Working Paper No. 6/01, Harvard Law School European Union Program.

Schmitter, P. C. (2003). 'Democracy in Europe and Europe's Democratization', Journal of Democracy, 14 (4), pp. 71-85.

Shaw, J. (1997). 'Citizenship of the Union: Towards Postnational Membership?', Harvard Jean Monnet Working Paper, No. 6/97.

Shaw, J. (1998). 'The Interpretation of European Union Citizenship', Modern Law Review 61, pp.293-317.

Smismans, S. (1999). 'An Economic and Social Committee for the Citizen, a Citizen for the Economic and Social Committee?', European Public Law, 5 (4), pp. 569-73.

Streeck, W. (2000)' "Competitive Solidarity: Rethinking the "European Social Model"', in Kontingenz und Krise: Institutionenpolitik in kapitalistischen und postsozialistischen Gesellschaften, Karl Hinrichs et al. (eds.). (Frankfurt/M., Campus), pp. 245-261.

TEU (1992). "Treaty on European Union”, Official Journal C 191, 29 July 1992.

Tsebelis, G. (2002). Veto Players. How Political Institutions Work. Princeton: Princeton University Press.

Wallace, H. (1993). 'Deepening and Widening: Problems of Legitimacy for the EC', in Soledad Garcia (ed.) European Identity and the Search for Legitimacy (London: Pinter), pp. 95-105.

Warleigh, A. (1998). 'Frozen: Citizenship and European Unification', Critical Review of International Social and Political Philosophy, 4 (1),pp.113-51.

Weber, M. (1946). From Max Weber: Essays in Sociology, translated by Hans H. Gerth and C. Wright Mills. New York: Oxford University Press. 
Weber, M. (1964). The Theory of Social and Economic Organization, translated by A.M. Henderson and Talcott Parsons (ed.), London: The Free Press, 1964 (first edition: 1947).

Weiler, J. (1993). 'After Maastricht: Community Legitimacy in Post-1992 Europe', in William J. Adams (ed.) Singular Europe. Economy and Polity of the European Community after 1992, Michigan: Univ. of Michigan Press, pp. 11-41.

Weiler, J. (1999) 'To be a European Citizen: Eros and Civilization', in J. Weiler The Constitution for Europe. Cambridge: Cambridge University Press.

Wessels, W. (1996) 'The Modern West European State and the European Union: Democratic Erosion or a New Kind of Polity?', in Svein S. Andersen and Kjell A. Eliassen (eds.) The European Union: How Democratic Is It? London: SAGE Publications, pp. 57-69.

Wessels, W. and Diedrichs, U. (1997). 'A New Kind of Legitimacy for a New Kind of Parliament - The Evolution of the European Parliament', European Integration online Papers (EloP), 1 (6), available at: http://eiop.or.at/eiop/pdf/1997-006.pdf.

Wiener, A. (1998). A European Citizenship. Boulder: Westview Press.

Zielonka, J. (2007)' 'Plurilateral Governance in the Enlarged European Union', Journal of Common Market Studies, 45 (1), pp. 187-209. 